\title{
PENGARUH KUALITAS PRODUK, HARGA DAN PROMOSI TERHADAP KEPUTUSAN PEMBELIAN KARTU PERDANA PRABAYAR XL DI KOTA PADANG
}

\author{
Yelvi Eka Putri, H. Anoesyirwan Moiens, Yulasmi \\ Universitas Putra Indonesia YPTK Padang, Indonesia \\ email: Yelviekaputri8@yahoo.com
}

\begin{abstract}
Penelitian ini bertujuan untuk mengetahui seberapa besar Pengaruh Kualitas Produk, Harga dan Promosi Terhadap Keputusan Pembelian Kartu Perdana Prabayar XL, metode pengumpulan data ini adalah dengan mengedarkan kuisioner dengan sampel 100. Metode analisis yang digunakan adalah analisis regresi berganda . Hasil penelitian yang diperoleh dengan persamaan $Y=\mathbf{1 8 , 3 2 3 + 0 , 4 3 4 X 1 - 0 , 1 3 4 X 2 + 0 , 2 6 3 X 3 + e : ~ ( a ) ~ K u a l i t a s ~ P r o d u k ~ m e m i l i k i ~}$ pengaruh sebesar 0,434 terhadap keputusan pembelian. Maka Kualitas Produk memiliki pengaruh yang positif dan signifikan. (b) Harga memiliki pengaruh negative sebesar 0,134 terhadap keputusan pembelian. Maka Harga memiliki pengaruh yang positif dan signifikan. (c)Promosi memiliki pengaruh sebesar 0,263 terhadap keputusan pembelian. Maka Promosi memiliki pengaruh yang positif dan signifikan. (d) Kualitas Produk, Harga dan Promosi memiliki pengaruh sebesar 18,323 terhadap keputusan pembelian. Maka secara bersama-sama Kualitas Produk, Harga dan Promosi memiliki hubungan yang positif dan signifikan. Dan berdasarkan uji koefisien Determinasi $\left(\mathrm{R}^{2}\right)$ ini menunjukan bahwa besarnya persentase kontribusi dari variable kualitas produk, harga dan promosi terhadap keputusan pembelian adalah sebesar $42,3 \%$ dan sisanya sebesar 57,7\% yang dipengaruhi oleh variable lain yang tidak termasuk dalam penelitian ini. Hasil dari analisis korelasi diperoleh R sebesar 0,664 dan R square sebesar 0,441 . Hal ini menunjukan bahwa terjadi hubungan yang kuat antara kualitas produk, harga dan promosi terhadap keputusan pembelian. Akhirnya penulis menyarankan Kartu Perdana Prabayar XL diharapkan dapat meningkatkan Kualitas Produk, Harga dan Promosi.
\end{abstract}

Keywords: Decision Purchasing, Quality Product, Price, Promotion

\section{PENDAHULUAN}

Didalam kehidupan yang semakin modern ini, dimana tingkat persaingan semakin ketat dalam ilmu pengetahuan, ilmu teknologi, maupun informasi, maka masalah yang dihadapi dunia usaha semakin rumit. Perkembangan ekonomi serta dukungan sarana transportasi yang cukup banyak, berdampak secara langsung terhadap mobilitas manusia itu sendiri.

Pt Excelcomindo Pratama Tbk (xl) telah membangun lebih dari 1600 BTS, dengan demikian per tangggal 30 Juni 2007, XL telah memiliki hamper 9000 BTS diseluruh Indonesia dengan jangkauan 85\% penduduk Indonesia . XL telah mengambil langkah-langkah kedepan untuk lebih meningkatkan kualitas jaringannya kepada para pelanggan, juga meningkatkan cakupan jaringan dan kapasitas dengan membelanjakan belanja modal sebesar Rp 2,9 Triliun pada semester pertama tahun 2007. Jumlah tersebut lebih tinggi dari pada belanja modal semester pertama tahun 2006 yaitu Rp 2,3 Triliun. Jumlah BTS yang didalamnya sudah termasuk 3G node B, telah meningkat 59\% dari 5606 BTS pada semester pertama 2006 menjadi 8936 BTS pada semester pertama 2007.

Suatu produk akan mempunyai nilai lebih dimata konsumen jika perusahaan mengetahui perilaku konsumen dalam kaitannya dengan keputusan untuk membeli baik barang ataupun jasa untuk mengetahui apa yang menjadikan konsumen memutuskan pembelian suatu produk maka perlu ditentukan atributatribut yang mendukung. Berikut ini disajikan data volume penjualan Kartu Perdana XL periode 20102014: 
Tabel 1.1

Data Volume Penjualan Kartu Perdana Prabayar XL di Kota Padang

\begin{tabular}{|l|l|l|}
\hline Tahun & Volume penjualan(unit) & Persentase pertumbuhan \\
\hline 2013 & 46,72 Ribu & $25,88 \%$ \\
\hline 2014 & $38,00 \mathrm{Ribu}$ & $21,05 \%$ \\
\hline 2015 & $32,70 \mathrm{Ribu}$ & $18,12 \%$ \\
\hline 2016 & 31,63 Ribu & $17,52 \%$ \\
\hline 2017 & $31,46 \mathrm{Ribu}$ & $17,43 \%$ \\
\hline
\end{tabular}

\section{Sumber : $\underline{\text { ww.okezone.com }}$}

Dari table diatas fenomena yang ada pada tahun 2013 terdapat jumlah volume penjualan sebesar 46,72 ribu dengan persentase pertumbuhan $25,88 \%$, pada tahun 2014 volume penjualan sebesar 38,00 ribu dengan jumlah persentase pertumbuhan sebesar 21,05\%, kemudian pada tahun 2015 volume penjualan sebesar 32,70 ribu dengan jumlah persentase pertumbuhan 18,12\%, dan pada tahun 2016 jumlah penjualan kartu perdana prabayar XL sebesar 31,63 ribu dengan jumlah persentase pertumbuhan 17,52\%, sedangkan pada tahun 2017 jumlah penjualan kartu perdana tersebut sebesar 31,46 ribu dengan jumlah persentase pertumbuhan $17,43 \%$.

Dari data tabel tersebut dapat disimpulkan bahwa dari tahun ketahun kartu perdana XL mengalami penurunan terhadap volume pejualan yang mengakibatkan persentase pertumbuhan juga menurun. Hal ini disebabkan oleh kurangnya kualitas produk terhadap jaringan dan layanan dan disediakan. Dengan adanya hal tersebut maka kurangnya kepercayaan konsumen terhadap produk XL. Dan begitu juga dengan harga lebih tinggi jika di bandingkan dengan produk lain. Di samping itu jika dilihat dari promosi nya juga tidak efektif jika dibandingkan dengan kenyataannya. Karena promosi jaringan yg dipromosikan tidak mencapai ke daerah-daerah terpencil. Oleh karena itu, volume penjulan harus di tingkatkan lagi, dengan cara meningkatkan kualitas produk, harga dan promosi sehingga jumlah dari persentase pertumbuhan akan meningkat,dan begitu juga dengan tujuan dari perusahaan akan tercapai. Dengan demikian keputusan pembelian terhadap kartu perdana XL dapat meningkat dari tahun ke tahun. Oleh karena itulah peneliti tertarik untuk melakukan penelitian pada Kartu Perdana Prabayar XL ini.

\section{LANDASAN TEORI}

\section{Pemasaran}

Pemasaran adalah megidentifikasi dan memenuhi kebutuhan manusia dan sosial.Salah satu definisi ssingkat dari pemasaran adalah memenuhi kebutuhan dengan cara menguntungkan. Karenanya manajemen pemasaran sebagai seni dan ilmu memilih pasar sasaran dan meraih, mempertahankan, serta menumbuhkan pelanggan dengan menciptakan, menghantarkan, dan mengkomunikasikan nilai pelanggan yang unggul. Periset dapat membagi aliran ini ke dalam beberapa tahap dan subproses yang berbeda untuk menyederhanakan masalah (problem solving) genetik yang menjelaskan lima tahapan atau proses dasar.

Philip Kotler dan Amstrong (2008 : 6) mengemukakan model sederhana dari lima langkah proses pemasaran. Langkah-langkah model pemasaran yang sederhana adalah sebagai berikut :
a. Memahami pasar dan kebutuhan serta keinginan pelanggan
b. Merancang strategi pemasaran yang digerakkan oleh pelanggan
c. Membangun program pemsaran terintegrasi yang memberikan nilai yang unggul
d. Membangun hubungan yang mengutungkan dan menciptakan kepuasan pelanggan
e. Menangkap nilai dari pelanggan 


\section{Pengertian Keputusan Beli}

Menurut Dr.Etta Mamang dan Dr.sopiah (2013:123) keputusan pembelian konsumen adalah proses pemecahan masalah yang diarahkan pada sasaran. Pemecahan masalah konsumen sebenarnya merupakan suatu aliran tindakan timbal balik yang berkesinambungan diantara factor lingkungan, proses kognitif dan afektif, serta tindakan perilaku.

Model Perilaku Konsumen

Model perilaku konsumen menurut Thamrin Abdullah dan Francis Tantri (2014:112) yaitu :

Tabel 2.2

Model Perilaku Konsumen

\begin{tabular}{|l|l|l|l|l|}
\hline $\begin{array}{l}\text { Stimulasi } \\
\text { pemasaran }\end{array}$ & $\begin{array}{l}\text { Stiulasi } \\
\text { lainnya }\end{array}$ & $\begin{array}{l}\text { Karakteristik } \\
\text { pembeli }\end{array}$ & $\begin{array}{l}\text { Proses Kebutuhan } \\
\text { Pembelian }\end{array}$ & Keputusan Pembeli \\
\hline $\begin{array}{l}\text { Produk } \\
\text { Harga }\end{array}$ & Ekonom & Budaya & Pengenalan & Pilihan produk \\
Promosi & Sosial & masalah & Pilihan merek \\
Distribusi & Teknolo & Pribadi & Pencarian & Pilihan pemasok \\
& gi & Psikologis & informasi & Kentuan saat \\
& Politik & & $\begin{array}{l}\text { Keputusan } \\
\text { pembeli }\end{array}$ & Jumlian pembelian \\
& Budaya & & Perilaku purnabeli & \\
\hline
\end{tabular}

Adapun indikator dari proses keputusan pembelian konsumen dalam penelitian ini adalah (J.Paul Peter Jerry C.Olson (2013:165) :Pengenalan masalah, pencarian berbagai alternative solusi, evaluasi berbagai alternatif solusi, keputusan pembelian dan penggunaan pasca pembelian dan evaluasi ulang alternative yang dipilih.

\section{Pengenalan Masalah}

Persepsi mengenai perbedaan kondisi ideal dan actual.

2. Pencarian berbagai alternative solusi

Mencari informasi relevan mengenai berbagai solusi yang berpotensi menyelesaikan masalah lingkungan eksternal, atau mengaktifkan pengetahuan memori.

3. Evaluasi berbagai alternatif solusi

Mengevaluasi dan menilai berbagai alternative dalam arti kepercayaan menonjol mengenai berbagai konsekuensi relevan dan menggabungkan pengetahuan tersebut untuk membuat pilihan.

4. Keputusan pembelian Membeli alternatif yang dipilih.

5. Penggunaan pasca pembelian dan evaluasi ulang alternative yang dipilih Menggunakan alternatif yang dipilih dan mengevaluasinya lagi untuk mengetaui hasil kerjana.

\section{Pengertian Kualitas Produk, Harga dan Promosi}

Kualitas Produk

Menurut Dr.Thamrin Abdullah dan Dr.Francis Tantri (2014:153) kalau didefinisikan secara luas produk meliputi objek secara fisik, pelayanan, orang, tempat, organisasi, gagasan atau bauran dari semua wujud diatas. Jasa adalah produk yang terdiri dari aktifitas, manfaat atau kepuasan yang dijual.

Menurut Kotler dan Kevin Lane Keller (2013:4) produk adalah segala sesuatu yang dapat ditawarkan kepada pasar untuk memuaskan suatu keinginan atau kebutuhan termasuk barang fisik, jasa, pengalaman, acara, orang, tempat, property, organisasi, informasi dan ide. 
Kotler dan Amstrong (2010:27) mengemukakan bahwa kualitas produk adalah kemampuan suatu produk untuk melaksanakan fungsinya, meliputi kehandalan, daya tahan, ketepatan, kemudahan operasi dan perbaikan produk serta atribut bernilai lainnya.

\section{Klasifikasi Produk}

Menurut Philip Kotler dan Kevin Lane keller(2013:6) dulu pemasar mengklasifikasikan produk berdasarkan ketahanan, keberwujudan dan kegunaan (konsumen atau industri). Setiap jenis produk mempunyai strategi bauran pemasaran. Ketahanan dan keberwujudan pemasar menggolongkan produk menjadi tiga kelompok menurut ketahanan dan keberwujudannya sebagai berikut :

1. Barang-barang yang tidak tahan lama

Barang-barang yang berwujud yang biasanya dikonsumsi dalam satu atau beberapa kali penggunaan. Strategi yang tepat adalah membuat barang-barang tersebut tersedia di banyak lokasi, hanya mengenakan markup yang kecil dan beriklan secara besar-besaran untuk mendorong percobaan dan membangun preperensi.

2. Barang tahan lama

Barang-barang ang berwujud yang biasanya dapat digunakan untuk waktu lama. Produk tahan lama biasanya memerlukan penjualan personal dan jasa, menuntut margin yang lebih tinggi dan memerlukan garansi penjual yang lebih banyak.

3. Jasa

Produk yang tak berwujud, tak terpisahkan, bervariasi dan dapat musnah. Akibatnya, jasa biasanya memerlukan kendali kualitas, kredibilitas pemasok dan kemampuan adaptasi yang lebih besar.

Klasifikasi produk menurut Dr.Thamrin Abdullah dan Dr.Francis Tantri (2014:155):

1. Produk konsumen

Produk konsumen adalah apa yang dibeli konsumen akhir untuk konsumen pribadi. Produk konsumen mencakup produk sehari-hari, produk shopping, produk khusus dan produk yang tidak dicari.

2. Produk industri

Produk industri adalah barang yang dibeli untuk diproses lebih lanjut atau untuk dipergunakan dalam menjalankan bisnis. Jadi perbedaan antara produk konsumen dan produk produk industri didasarkan pada tujuan produk tersebut dibeli.

3. Mutu produk

Mutu adalah salah satu alat penting bagi pemasar untuk menetapkan posisi. Mutu produk adalah kemampuan produk untuk melaksanakan fungsinya. Termasuk didalamnya keawetan, keandalan, ketepatan, kemudahan dipergunakan dan diperbaiki serta atribut bernilai lainnya.

4. Sifat-sifat produk

Suatu produk dapat ditawarkan dengan berbagai sifat. Sifat adalah alat bersaing untuk membedakan produk perusahaan dari produk bersaing.

5. Rancangan produk

Cara lain untuk menambah nilai bagi pelanggan adalah lewat rancangan produk yang membedakan. Rancangan adalah konsep yang lebih luas ketimbang gaya. Gaya hanya menguraikan tampilan produk. Seseorang perancang yang baik memerhatikan penampilan, tetapi juga menciptakan produk yang mudah, aman, murah untuk dipergunakan dan diservis, serta sederhana dan ekonomis untuk dibuat dan didistribusikan.

\section{Tingkatan Produk}

Menurut Assauri (2011:202) pada dasarnya produk yang dibeli konsumen itu dapat dibedakan atas tiga tingkatan,yaitu :

1. Produk inti (core product) 
Yang merupakan inti atau dasar yang sesungguhnya dari produk yang ingin diperoleh atau didapatkan oleh seorang pembeli atau konsumen dari produk tersebut.

2. Produk formal (formal product)

Merupakan bentuk,model,kualitas/mutu,merek dan kemasan yang menyertai produk tersebut.

3 . Produk tambahan (augemented product)

Merupakan tambahan produk formal dengan berbagai jasa yang menyertainya,seperti pemasangan Harga (instalasi),pelayanan,pemeliharaan dan pengangkutan secara cuma-cuma.

Kotler dan Amstrong (2008:264) menyatakan bauran pemasaran adalah kumpulan alat pemasaran taktis terkendaliyang dipadukan perusahaan untuk menghasilkan respon yang diinginkannya di pasar sasaran.Adapun unsur bauran pemasaran (4p) yang dibahas dalam penelitian ini yang salah satu variabelnya adalal harga.

\section{Tujuan Penetapan Harga}

Pada dasarnya ada empat jenis tujuan penetapan harga menurut Fandy Tciptono (2010:152) yaitu :

1. Tujuan Berorientasi Pada Laba Asumsi teori ekonomi klasik menyatakan bahwa setiap perusahaan selalu memilih harga yang dapat menghasilkan laba paling tinggi.Tujuan ini dikenal dengan istilah maksimalisasi laba.

2. Tujuan Berorientasi Pada Volume

Selain tujuan berorientasi pada laba,ada pula perusahaan yang menetapkan harganya berdasarkan tujuan yang berorientasi pada volume tertentu atau yang biasa dikenal dengan istilah volume pricing objectives.

3. Tujuan Berorientasi Pada Citra

Citra (image) suatu perusahaan dapat dibentuk melalui strategi penetapan harga.Perusahaan dapat menetapkan harga tinggi untuk membentuk atau mempertahankan citra prestisius.Sementara harga rendah dapat digunakan untuk membentuk citra nilai tertentu.

4. Tujuan Stabilisasi Harga

Dalam pasar yang konsumennya sangat sensiitf terhadap harga,bila suatu perusahaan menurunkan harganya maka pesaingnya harus menurunkan pula harga mereka.Kondisi seperti ini yang mendasari terbentuknya tujuan stabilisasi harga dalam industri-industri tertentu yang produknya sangat terstandarisasi (misalnya minyak bumi).

5. Tujuan-Tujuan Lainnya

Harga dapat pula diterapkan dengan tujuan mencegah masuknya pesaing,mempertahankan loyalitas pelanggan,mendukung penjualan ulang,atau menghindari campur tangan pemerintah.

\section{Promosi}

Menurut Ali Hasan (2013:603) promosi merupakan proses mengkomunikasikan variable bauran pemasaran yang sangat penting untuk dilaksanakan oleh perusahaan dalam memasarkan produk. Promosi juga merupakan fungsi dari pemasaran yang fokus untuk mengkomunikasikan program-program pemasaran secara persuasive kepada target pelanggan untuk mendorong terciptanya transaksi pertukaran antara perusahaan dan pelanggan.

Ada enam strategi pokok dalam strategi promosi menurut Fandy Tciptono (2010:233) yaitu :

1. Strategi pengeluran promosi

Anggaran promosi merupakan bagian dari anggaran pemasaran.Namun demikian tidak asa standar yang pasti mengenai seberapa besar pengeluaran untuk promosi yang harus dialokasikan.

2. Strategi bauran promosi

Strategi ini berupaya meberikan distribusi yang optimal dari setiap metode promosi.

3. Strategi pemilihan media 
Tujuan dari strategi ini adalah memilih media yang tepat untuk kampanye iklan dalam rangka membuat pelanggan menjadi tahu,paham,menentukan sikap,dan membeli produk yang dihsilkan perusahaan.

4. Strategi copy iklan

Copy berfungsi untuk menjelaskan manfaat produk dan memberi alasan kepada pembacanya mengapa harus membeli produk tersebut.Copy yang efektif haruslah menarik,spesifik,mudah dimengerti,singkat,bisa dipercaya,sesuai dengan keinginan pembaca dan persuasif.

5. Strategi penjualan

Strategi penjualan adalah memindahkan posisi pelanggan ke tahap pembelian (dalam proses pengambilan keputusan) melalui penjualan tatap muka.

\section{Kerangka Fikir}

e

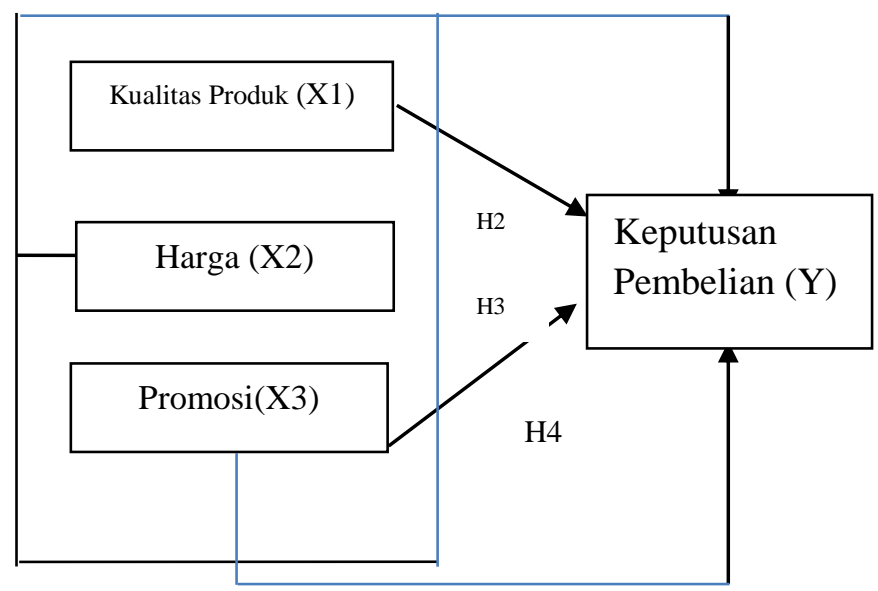

\section{Hipotesa}

1. Produk berpengaruh positif terhadap keputusan pembelian kartu perdana prabayar XL di Kota Padang.

2. Harga berpengaruh negatif terhadap keputusan pembelian kartu perdana prabayar XL di Kota Padang.

3. Promosi berpengaruh signifikan terhadap keputusan pembelian kartu perdana prabayar XL di Kota Padang.

4. Produk, harga dan promosi berpengaruh secara bersama-sama terhadap keputusan pembelian kartu perdana prabayar XL di Kota Padang.

\section{METODOLOGI PENELITIAN}

\section{Analisis Regresi berganda}

Analisis ini untuk meramalkan bagaimana keadaan (naik turunnya) variabel dependen (kriterium), bila dua atau lebih variabel independen sebagai faktor prediktor dimanipulasi (dinaik turunkan nilainya. Rumus (Sugiono,2014:192) :

$$
\mathrm{Y}=\mathrm{a}+\mathrm{b}_{1} \mathrm{X}_{1}+\mathrm{b}_{2} \mathrm{X}_{2}+\mathrm{b}_{3} \mathrm{X}_{3+\mathrm{e}}
$$

Keterangan :

$\mathrm{Y}=$ Keputusan Pembelian

$\mathrm{X}_{1}=$ Kualitas Produk

$\mathrm{X}_{2}=$ Harga

$\mathrm{X}_{3}=$ Promosi 


\author{
$\mathrm{a} \quad=$ Konstanta \\ $b_{1}, b_{2}, b_{3}=$ Koefisien regresi masing-masing variabel \\ $\mathrm{e}=$ Standar error
}

\title{
Uji Hipotesis
}

Interval estimasi yang kita kembangkan sebelumnya merupakan satu teknik didalam statistic untuk membuat kesimpulan (inference)tentang sifat populasiberdasarkan data sampel. Metode statistic lain yang juga bisa digunakan untuk membuat kesimpulan sifat populasi dari data sampel adalah uji populasi. Uji hipotesis adalah pengujian yang bertujuan untuk mengetahui apakah kesimpulan pada sampel dapat berlaku untuk populasi (Dwi Priyatno,2008:11).

\section{Pengujian Secara Parsial (Uji-t)}

Uji-t dilakukan untuk mengetahui tingkat signifikan pengaruh variabel bebas terhadap variabel terikat secara parsial, dengan langkah-langkah sebagai berikut :

1. Menentukan rumusan hipotesis :

a) Ho : $b_{1}=0$, berarti Kualitas Produk, Harga dan Promosi secara parsial tidak mempunyai pengaruh yang signifikan terhadap keputusan pembelian.

b) Ha : $b_{1} \neq 0$, berarti Kualitas produk, harga dan promosi secara parsial mempunyai pengaruh yang signifikan terhadap keputusan pembelian.

2. Menentukan nilai $\mathrm{t}_{\text {tabel }}$, pada derajat kebebasan $(\mathrm{d}, \mathrm{f})=\mathrm{n}-\mathrm{k}-1$, dengan $\alpha=5 \%$

3. Membandingkan $t_{\text {hitung }}$ dengan $t_{\text {tabel }}$.

4. Mengambil keputusan :

a) Bila $t_{\text {hitung }}<t_{\text {tabel }}$, maka Ho diterima sedangkan Ha ditolak, artinya menunjukkan Kualitas produk, harga dan promosi secara parsial tidak mempunyai pengaruh yang signifikan terhadap keputusan pembelian.

b) Bila $t_{\text {hitung }}>t_{\text {tabel }}$, maka Ha diterima sedangkan Ho ditolak, artinya Kualitas produk, harga dan promosi secara parsial mempunyai pengaruh yang signifikan terhadap keputusan pembelian.

Rumus (Dwi Priyatno,2008:84) :

Keterangan :

$$
\text { thitung }=\frac{r \sqrt{n-k-1}}{\sqrt{1-r^{2}}}
$$

$\mathrm{r} \quad=$ koefisien korelasi parsial

$\mathrm{k} \quad=$ jumlah variabel independen

$\mathrm{n} \quad=$ jumlah data (kasus)

\section{Pengujian Secara Simultan (Uji-F)}

Uji-F dilakukan untuk mengetahui tingkat signifikansi pengaruh variabel bebas terhadap variabel terikat secara bersama-sama, dengan langkah-langkah sebagai berikut :

1. Menentukan rumusan hipotesis :

a) Ho: $b_{1}=b_{2}=b_{3}=b_{4}=0$, berarti Kualitas produk, harga dan promosi secara bersama-sama tidak mempunyai pengaruh yang signifikan terhadap keputusan pembelian.

b) $\mathrm{Ha}: \mathrm{b}_{1} \neq \mathrm{b}_{2} \neq \mathrm{b}_{3} \neq \mathrm{b}_{4} \neq 0$, berarti Kualitas produk, harga dan promosi secara bersama-sama mempunyai pengaruh yang signifikan terhadap keputusan pembelian.

2. Menentukan nilai $\mathrm{F}_{\text {hitung }}$ pada $\alpha$ atau tingkat signifikansi $=5 \%$, dan derajat kebebasan $(\mathrm{d}, \mathrm{f}) \mathrm{df} 1=\mathrm{k}$ dan df $2=n-k-1$

3. Menentukan besarnya $F_{\text {hitung }}$

4. Mengambil keputusan :

a) Bila $F_{\text {hitung }}<\mathrm{F}_{\text {tabel }}$, maka Ho diterima berarti Ha ditolak. Artinya Kualitas produk, harga dan promosi secara bersama-sama tidak mempunyai pengaruh yang signifikan terhadap keputusan pembelian. 
b) Bila $\mathrm{F}_{\text {hitung }}>\mathrm{F}_{\text {tabel }}$, maka Ho ditolak berarti Ha Diterima. Artinya Kualitas produk, harga dan promosi secara bersama-sama mempunyai pengaruh yang signifikan terhadap keputusan pembelian.

Rumus (Dwi Priyatno,2008:81) :

$$
f \text { hitung }=\frac{\mathrm{R}^{2} / \mathrm{k}}{\left(1-R^{2}\right) /(n-k-1)}
$$

Keterangan :

$\mathrm{R}^{2} \quad=$ koefisien determinasi

$\mathrm{n} \quad=$ jumlah data (kasus)

$\mathrm{k} \quad=$ jumlah variabel independen

\section{HASIL DAN PEMBAHASAN PENELITIAN}

\section{Pengaruh Variabel Kualitas Produk terhadap keputusan pembelian}

Dari tabel diatas diketahi $t$ hitung $>\mathrm{t}$ tabel $(4,763>1,985)$ dengan tingkat signifikan $(0,000<$ $0,05)$, artinya secara parsial ada pengaruh yang signifikan antara kualitas produk dengan keputusan pembelian. Dengan demikian Ho ditolak Ha diterima.

\section{Pengaruh Variabel Harga terhadap keputusan pembelian}

Dari tabel diatas diketahi $t$ hitung $>\mathrm{t}$ tabel $(-2,010>1,985)$ dengan tingkat signifikan $(0,047<$ $0,05)$, artinya secara parsial ada pengaruh yang signifikan antara harga dengan keputusan pembelian. Dengan demikian Ho ditolak Ha diterima.

\section{Pengaruh Variabel Promosi terhadap keputusan pembelian}

Dari tabel diatas diketahi $t$ hitung $>\mathrm{t}$ tabel $(3,377>1,985)$ dengan tingkat signifikan $(0,001<0,05)$, artinya secara parsial tidak ada pengaruh yang signifikan antara promosi dengan keputusan pembelian. Dengan demikian Ho diterima Ha ditolak.

\section{KESIMPULAN}

Dari hasil penelitian yang telah penulis lakukan tentang "Pengaruh Diferensiasi, Promosi dan Positioning Terhadap Keputusan Pembelian Laptop Merek Asus (Studi Kasus Mahasiswa Fakultas Ekonomi Universitas Putra Indonesia "YPTK" Padang ". Maka dapat di tarik beberapa kesimpulan sebagai berikut:

1. Hasil analisis regresi berganda didapat persamaan dapat :

Dari persamaan di atas dapat dijelaskan sebagai berikut :

a. Kualitas produk memiliki pengaruh sebesar 0,434 terhadap keputusan pembelian. Maka kualitas memiliki pengaruh yang positif dengan signifikan 0,000. Maka demikian dengan Ho ditolak dan Ha diterima.

a. Harga memiliki pengaruh sebesar 0,-134 terhadap keputusan pembelian. Maka harga memiliki pengaruh yang positif dengan signifikan0,047. Maka demikian dengan Ho ditolak dan Ha diterima. 
b. Promosi memiliki pengaruh sebesar 0,263 terhadap keputusan pembelian. Maka promosi memiliki pengaruh yang positif dengan signifikan0,001. Maka demikian dengan Ho ditolak dan Ha diterima.

c. Kualitas produk, harga dan promosi memiliki pengaruh sebesar 18,323terhadap keputusan pembelian. Maka secara bersama-sama kualitas produk, harga dan promosi memiliki hubungan yang positif dengan signifikan 0,000. Maka dengan demikian Ho ditolak dan Ha diterima.

2. Dari hasil analisis determinasi, pengaruh kualitas produk, harga dan promosi, terhadap keputusan pembelian adalah sebesar 42,3 \%, sedangkan sisanya sebesar 57,7\% dipengaruhi oleh faktor lain. Maka secara bersama-sama antara penilaian produk, harga dan promosi mempunyai pengaruh yang signifikan terhadap keputusan pembelian.

3. Hasil analisis korelasi sebagai berikut:

a. Kualitas produk dengan keputusan pembelian memiliki hubungan yang kuat yaitu sebesar 0,434 dengan tingkat signifikan 0,000 .

b. Harga dengan keputusan pembelian memiliki hubungan yang kuat yaitu sebesar 0,-0,134 dengan tingkat signifikan 0,047 .

c. Promosi dengan keputusan pembelian memiliki hubungan yang kuat yaitu sebesar 0,263 dengan tingkat signifikan 0,001 .

\section{DAFTAR PUSTAKA}

Abdullah, Thamrin dan Francis tantri. 2012. Manajemen Pemasaran. Jakarta: PT Rajagrafindo Persada. Alma, Buchari. 2011. Manajemen Pemasaran dan Pemasaran Jasa. Bandung: Alfabeta.

Assauri, Sofjan. 2014. Manajemen Pemasaran. Jakarta: PT Rajagrafindo Persada.

Hasan, Ali. 2013. Marketing dan Kasus-Kasus Pilihan. Yogyakarta: CAPS

Center For Academic Publishing.

Kotler, Philip dan Kevin Lane Keller. 2009. Manajemen Pemasaran, Edisi Ketiga Belas, Jilid 1. Jakarta: Erlangga.

Kotler, Philip dan Kevin Lane Keller. 2013. Manajemen Pemasara. Edisi Ketiga Belas, Jilid 1. Jakarta: Erlangga.

Lupiyoadi, Rambat dan A.Hamdani. 2008. Manejemen Pemasaran Jasa. Jarakta: Salemba Empat.

Peter, J.Paul dan Jerry C.Olson. 2013. Prilaku Konsumen dan Strategi Pemasaran. Jakarta: Salemba Empat.

Priyatno, Dwi. 2008. SPSS (Statistical Product And Service Solution Untuk Aanalisis Data \& Uji Statistic). Yogyakarta: Mediakom.

Sangadji, Etta Mamang dan Sopiah. 2013. Prilaku Konsumen. Yogyakarta: Andi.

Sugiyono. 2014. Metode Penelitian Kuantitatif, kualitatif dan R\&D. Bandung: Alfabeta.

Tjiptono, Fandy. 2008. Strategi Pemasaran. Yogyakarta: Andi

Tjiptono, Fandy dkk. 2008. Strategi Strategik. Yogyakarta: Andi

Tjiptono, Fandy dkk. 2009. Strategi Pemasaran. Jakarta: Andi 